\title{
<合同シンポジウムII >
}

\section{経頭蓋超音波 harmonic perfusion imagingによる 脳組織灌流動態の評価}

\author{
塩具 敏之 ${ }^{1)}$ 上坊 千春" ${ }^{11}$ 越村満理子1) \\ 野村 英憲" 土井 淳史 ${ }^{21}$ 牧野 雅弘 ${ }^{31}$ \\ 水野 敏樹3) 中島 健二3” 古幡 博 ${ }^{4}$

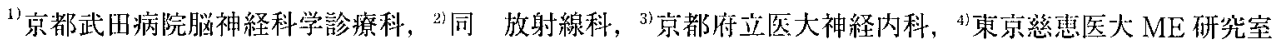

Key words : 経頭蓋ハーモニック脳組織灌流画像, 超音波造影剤, ダイナミック CT, 経頭蓋 超音波ドプラ，アセタゾラマイド脳血管反応性

(脳卒中 $24: 526-534,2002$ )

\section{I.はじめに}

超音波造影率を用いた脳組織灌流の評価は，従来頭 蓋骨の切除が必要で寒験的に試みられていた。しかし 診断機器と技術の進歩で harmonic 法が利用可能とな り, harmonic perfusion imaging（HPI）として経頭蓋 的な評洒法が臨床に導入され》，実験的にも臨床的に も広く検討が行われている(Table 1)。この経頭蓋 HPI は, 脳組織灌流動態を非侵襲的かつ比較的簡便にベッ ドサイドでも評価できることから，とくに虚血性脳血 管障害急性期への応用が試みられている。しかし，そ の適切な画像描出法などの定性的にも，また SPECT, dynamic CT (DCT), perfusion MRI よ゙の ような定量的脳循環測定法としても，その臨床的な意 義や信頼性は未確立である，そこで我々はその確立を 目的として, 定性的に HPI の各種画像描出法の比較, 定量的に超音波造影剤の bolus 静注法と新しい持続静 注法による解析を, acetazolamide (ACZ) 負荷による 脳血管反応性も導入して, 経頭蓋超音波 Doppler （TCD）やDCT との関係から検討した.

\section{II. 方 法}

超音波造影剤 Levovist が本邦でも利用可能となっ た 1999 年 9 月以降の各種神経疾患成人例を対象とし た. 経頭盍 HPI の定性的検討には, Levovist ${ }^{\text {(3) }} 300 \mathrm{mg} /$ $\mathrm{ml} 2.5 \mathrm{~g}$ bolus 静注後に, 診断装置 (SONOS5500) の送 信/受信周波数 $(\mathrm{MHz})$ に基づき，S4 探触子 (1.8/3.6)
の integrated backscatter (IBS) 法による gray-scale second harmonic imaging (SHI) と power Doppler (PD) 法による power harmonic imaging (PHI) (Fig. 1A), S3 探触子の ultraharmonic imaging (UHI) (1.3/ 3.6), SHI2.6 (1.3/2.6), PHI2.6 (B-mode $1.6 / 3.2$, PD 1.3/2.6), PHI3.2 (B-mode 1.6/3.2, PD 1.6/3.2) にて (Fig. 1B)，側頭空加側頭葉 (TL), 基底核 $(\mathrm{BG})$ ，視 床（Th）を含む水平断の画像を描出し比較した，定量 的検討は, S4 挆触子を用いIBS 法による SHIにて, 同 様の bolus 静注法に加え, $400 \mathrm{mg} / \mathrm{ml} 2.5 \mathrm{~g}$ を $1 \mathrm{ml} / \mathrm{min}$ で持続静注し解析した，HPI の基本設定は，測定深度 $12 \mathrm{~cm}$, focus $6 \mathrm{~cm}$ に扔き, system gain 75 , compression 70, mechanical index (MI) は IBS 法で 1.5, PHI 法で 1.6, PHI の color gain 40\%, threshold 10, 繰り返 し周波数 $3.9 \mathrm{KHz}$, filter 4 に設定した，持続静注法で は, B-modeによるSHIでMI1.6にて行なった.HPI 画像は, bolus 静注法で 2 心拍に 1 回または 2 秒に 1 回, 持綍静注法では各パルス幅で 5 10データずつ, 計 62 又は 124 デー夕を光磁気ディスクに取り込み， acoustic densitometryにて time-intensity curve(TIC) を定量解析した（Fig. 2A)。DCTは，TCT700Sにて Ioversol $320 \mathrm{mgI} / \mathrm{m} l$ t $0.65 \mathrm{ml} / \mathrm{kg}$ bolus 静注後 14 scan 撮像し, $\gamma$-fitting した time-density curve (TDC) を解析した. TCDは，側頭空より中 (MCA) ・後大脳 動脈の平均血流速度 $(\mathrm{Vm})$ を計測した。

評価は，a）画像描出性の比較：1）S4 探触子のSHI と PHI (n=28) (Fig. 1A)，2） S3 探触子のUHI, SHI 
Table 1 超音波造影剂による腷組織灌流の評哂と画像抽出法

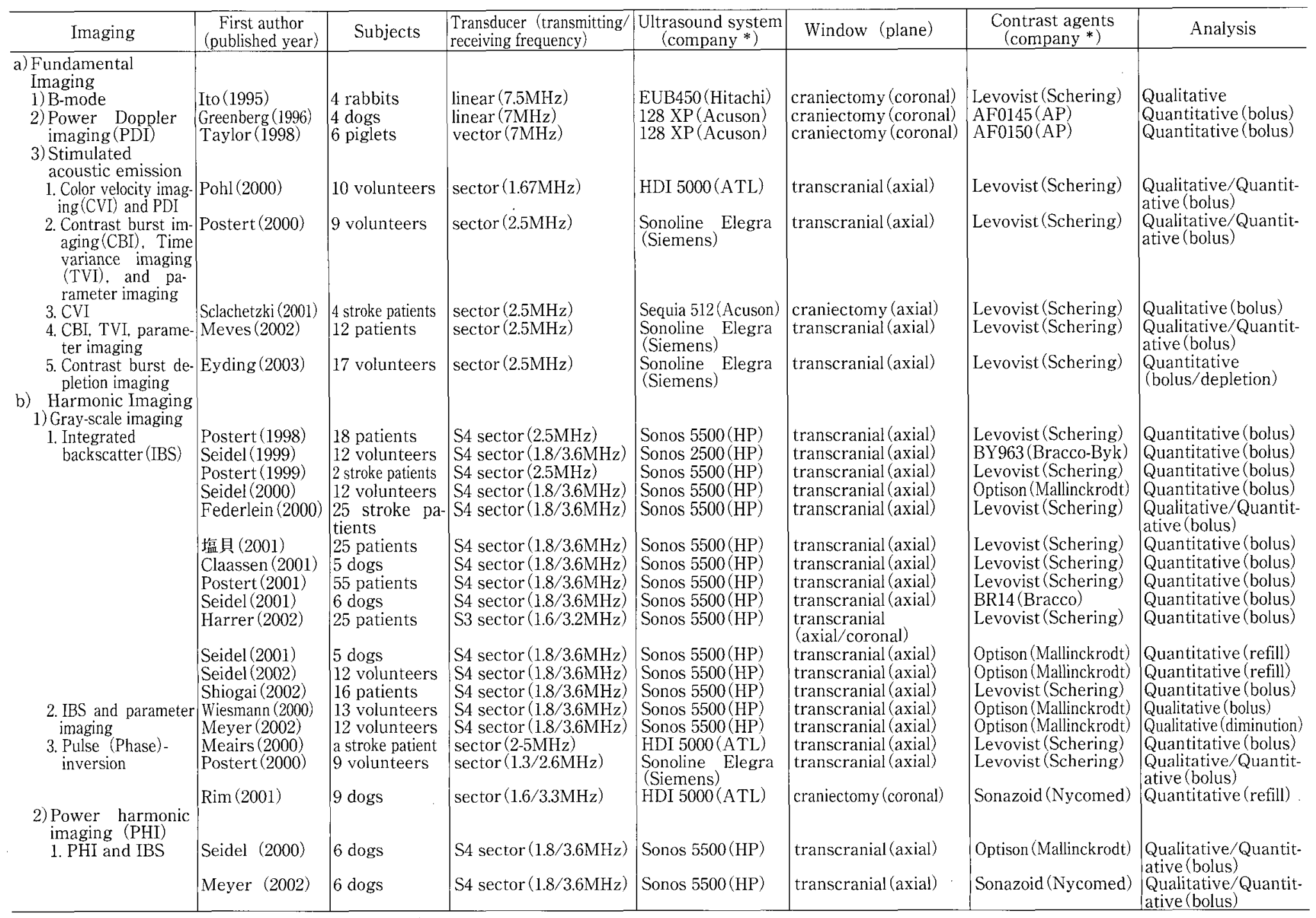

${ }^{*}$ HP. ATL $=$ Philips, $\mathrm{AP}=$ Alliance Pharmaceutical. 


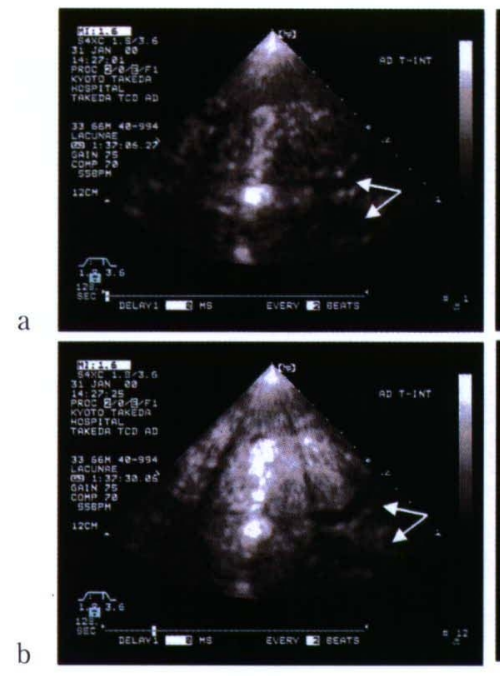

SHI $(1.8 / 3.6 \mathrm{MHz})$

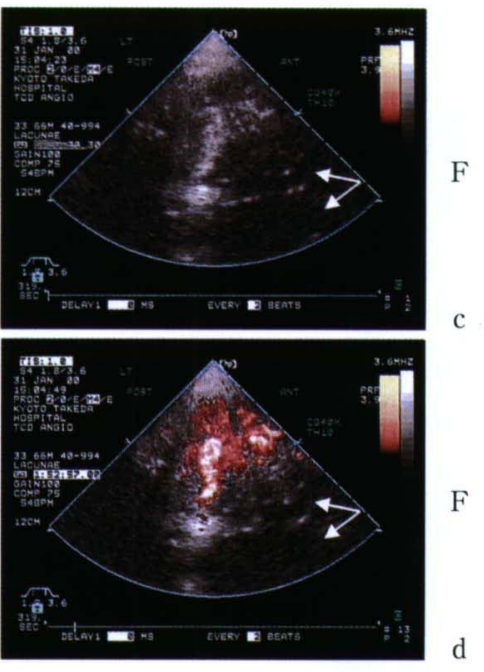

PHI $(1.8 / 3.6 \mathrm{MHz})$

Fig. 1 HPI の各種画像描出法の比較

前頭側を F で, 両側脳室前角を矢印で示す.

Fig. 1 (A)：S4 探触子による SHI と PHI

66 歳男, 左頭頂葉ラクナ梗塞例。左側頭空より, SHI を左 (a, b) , PHI を右 (c, d) に, 増強前（ $\mathrm{a}, \mathrm{c} ）$ を上，後（b，d）を下に示す，SHIの増強範囲は広いが，増強境 界はPHI が明瞭である.

SHI $(1.3 / 2.6 \mathrm{MHz})$
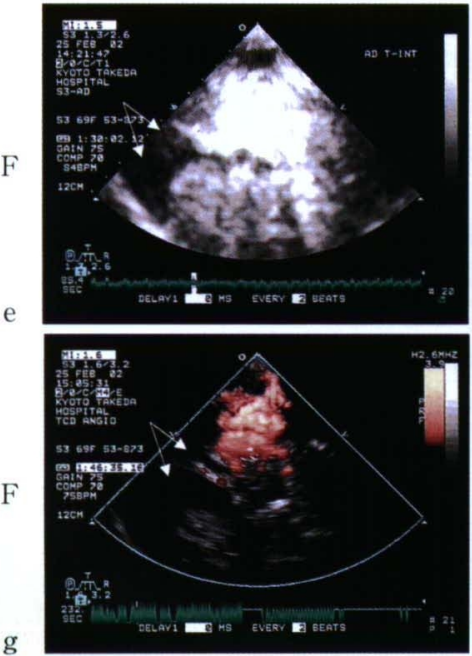

PHI $(1.3 / 2.6 \mathrm{MHz})$
UHI $(1.3 / 3.6 \mathrm{MHz})$
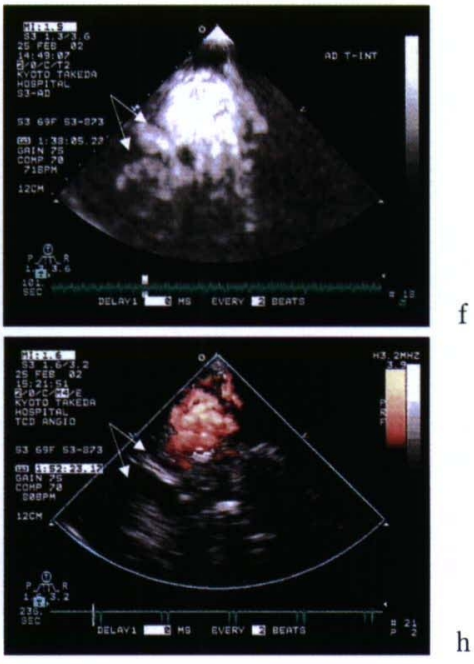

PHI $(1.6 / 3.2 \mathrm{MHz})$

Fig. 1 HPI の各種画像描出法の比較

Fig. 1(B)：S3 探触子による SHI, UHI, PHI

69 歳女, 前大脳動脈瘤術後, 右側頭空（骨欠損部）より描出. 増強範囲は, 左上より SHI (e), UHI (f), PHI2.6 (g), PHI3.2（h）の順に小さくなった. 
2.6, PHI (2.6 と 3.2) ( $\mathrm{n}=10)$ (Fig. 18), b) 定量性の検 討：1）bolus 注入法によるSHI と DCT の相関：3 関 心領域 ROI（TL, BG, Th）の TICと TDCのパラ $x-夕(\mathrm{PI}=$ peak intensity, $\mathrm{PH}=$ peak height, $\mathrm{AT}$ $=$ arrival time, $\mathrm{PT}=$ peak time, $\mathrm{TP}=$ time to peak, $\mathrm{AUC}=$ area under curve, $\mathrm{MTT}=$ mean transit time, CMTT $=$ corrected mean transit time）間 関 (n=25)（Fig. 2C)．2） bolus 注入法による脳血管反

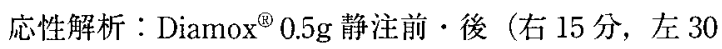
分) の SHI と TCD, 負荷前 - 後 15 分の DCT との比較 $(\% \Delta=$ 負荷前值 - 負荷後值/負荷前值 $\times 100)(\mathrm{n}=12)$,

3）持続静注法：送信パルス幅を $250 \sim 4,000 \mathrm{~ms}$ まで変 化させた時の増強強度の変化 (Fig. 3A)を, 3ROI で評 価 (Fig. 3B) し，ささらに ACZ 負荷前・後 30 分で比較 して (Figs.3Cと3D), 得られた定量的なデー夕を, $\mathrm{Y}=\mathrm{A} \quad\left(1-\mathrm{e}^{-\beta 1}\right)$ の式 ${ }^{2 !} に$ fitting させ検討した.

\section{III. 結 果}

a）画像描出性の比較

1）S4 探触子のSHI と PHI : 増強範囲を最大径（5 $\mathrm{cm}>, 3 \sim 5 \mathrm{~cm}, 3 \mathrm{~cm}<$, 造影不能)で比較すると, そ れぞれの症例数は SHI $(n=53)$ で $13(25 \%), 18(34$ $\%), 21(40 \%), 1(2 \%)$, PHI $(\mathrm{n}=52)$ で $3(6 \%)$, $14(27 \%), 27(52 \%), 8(15 \%)$ と, PHI ๖り $\mathrm{SHI}$ の方が増強範囲も㕕く, 感度も高かった(Fig. 1A).2) $\mathrm{S} 3$ 探触子での SHI2.6, UHI, PHI2.6, PHI3.2 ( $\mathrm{n}=$ 10）:同様に増强範囲を比較すると，それぞれの症例数 は SHI2.6 で 6, 0, 2, 2, UHI は 2, 4, 2, 2, PHI2.6 は $0,3,7,0, \mathrm{PHI} 3.2$ で 0, 0, 9, 1 と, 明らかに増 強範囲はSHI2.6>UHI >PHI2.6>PHI3.2の順に低下 した. 受信周波数の低いSHI2.6は高いUHI より,低い PHI2.6 は高いPHI3.2より增强籍团は広かった。また 別に骨弁のない例で検討しても同様の傾向が得られた (Fig. 1B)。また gray-scale の SHI と UHIは, PHIょり 増強範围は広かった。一方, 増強部位と背景との境界 は, SHIよりUHIや PHIが明瞭であったが, UHI や PHI3.2では背景画像の描出性が悪く, 増強部位の正確 な局在判定が困難であった.

b）定量性の検討

1）bolus 静注法による SHI と DCT 各パラメータ間 の相関 $(\mathrm{n}=25)$ ：SHI の PI (Fig. 2B) とAUC は深度 依存性に低下し，DCT との相関低下の主因であった。 各パラメータ間の相関を各 ROI で左右別に比較文る と, 比較的 MTT の相関係数が高かった(Fig. 2C)，2) bolus 静注法による腮血管反応性：ACZ負荷後の SHI 増強範囲掂大は, 右 $75 \%$, 左 $42 \%$ に視認でき, TCD 変化率 $(\% \Delta \mathrm{Vm})$ は, $\mathrm{MCA}$ で右 $24 \pm 22 \%$, 左 $13 \pm 18$ \%と同様の傾向が得られた。 DCT との関係にて％ $\Delta \mathrm{PI}(\mathrm{PH})$ と\% $\Delta \mathrm{AUC}$ は, ROI 局在で異なり, 共に右 TL と左 BG で低下傾向で，\% Thで延長傾向がみられた．3）持続静注法による解 析：送信パルス幅の増加に伴い增強強度 $(\mathrm{V})$ も上昇 (Fig. 3A）し，ほぼ一定になる傾向 (Fig. 3B) が得られ た.さらに $\mathrm{ACZ}$ 負荷後には増強強度上昇率 $(\beta)$ と強 度（A）自体も上昇した（Figs. 3C，3D）。

\section{IV. 考按}

a）超音波造影剤を用いた脳組織灌流画像と経頭蓋 harmonic imaging

超音波造影剤を用いた経頭蓋的な脳組織灌流画像の 評価には，IBS 法による gray-scale SHI が最も広く用 いられており (Table 1), 本シリーズでも画像描出性の 評価に応用した。 その結果, PD 法による SHIを harmonic B-mode 画像上に描出する PHI 法より，画像描 出性に優れているのが明らかとなった. 同様の結果は, 用いた造影剂の種類と送信音圧が異なるが，同機種の 同じ送信・受信周波数特性を持つ探触子による犬の実 験でも指摘されている31. IBS 法は, 超音波造影剤であ る微小気泡のみならず脳組織自体から後方散乱してき た超音波の生信号（radiofrequency signals）を積分し て描出する方法である。これと harmonic 法の併用に より，送信音压が比較的低くても，生じる微小気泡の 振動や共振により生じる非線形信号を捕らえる上で, harmonic B-mode 法より優れている。一方，PD法は Doppler 信号を積分したパワーを画像化したものであ るが, 脳組織の細動脈から毛細血管内にある気泡の遅 い動き程度の信号では画像描出上不充分で，描出のた めには微小気泡の破壊時に生じる強い非線形信号が必 用と推測されている 泡の破壊時に生じる強い信号は, 気泡自体が動かなく ても生じる偽 Doppler 現象で, stimulated acoustic emission と呼ばれ, harmonic 法でなくても通常の color Doppler 法による基本波画像でも捕らえ得るが， より PD 法が適切で B-mode 法より優れるとされてい る゙. しかし, 基本波を用いた PD 法では太い動脈から の blooming と呼ばれる増強効果の血管からのはみ出 し現象が生じるため, 主幹動脈近傍の組織灌流の評価 には不適切である。さらに,この PD 法を進展させた 

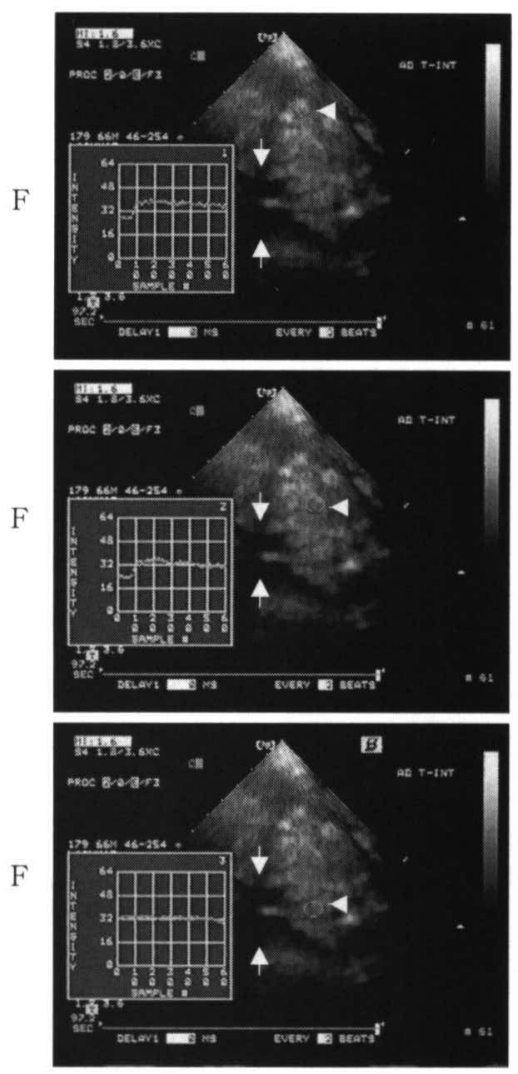

R
Temporal Lobe (TL)

Basal genglia (BG)

Thalamus (Th)
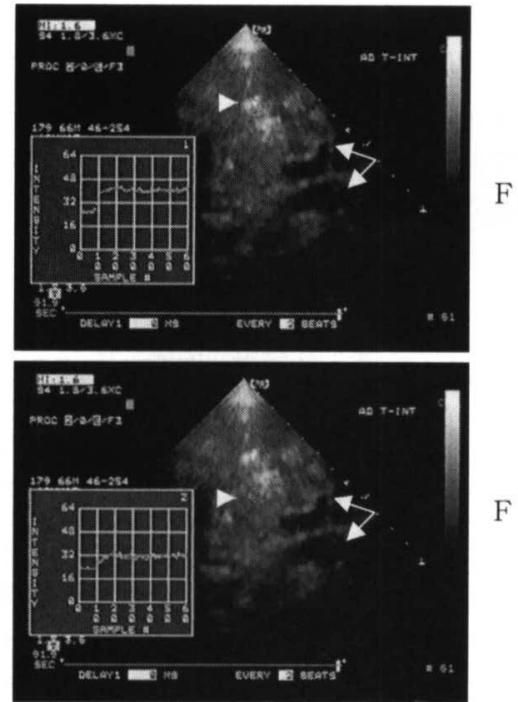

F

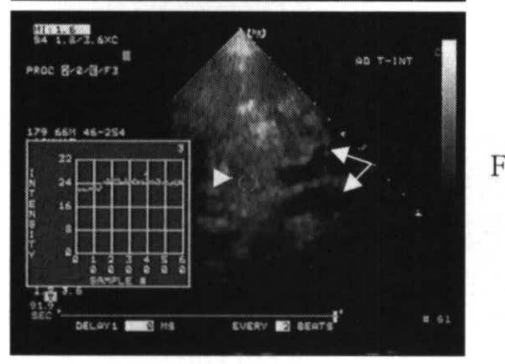

L

Fig. 2 Bolus 静注法による定量解析 ${ }^{8}$

Fig. 2 (A) : TIC 解析 ${ }^{8)}$

66 歳男, 放線冠のラクナ梗塞. $\mathrm{R}$ 列は右側頭窓, L 列は左側頭空からの画像で, 矢印 は側脳室前角各 ROI（矢頭）における TIC 解析を各々左下に示す.

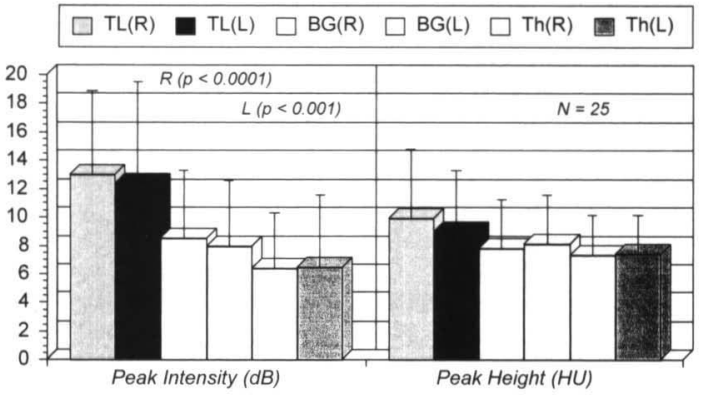

Fig. 2(B)：各 ROIにおけるHPIの peak intensity (PI) と dynamic CT の peak height との関係 HPI の PI は, TL, BG, Th と深度依存性に有意に低 下した。 contrast burst imaging や time variance imaging のよ うに，送信強度を上げパルス幅と取り込み時間を短く

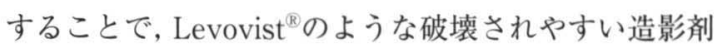
に適したimaging が導入されている5).これは, 送信 パルスを反転させ受信信号の増強を期待する pulseinversion 法を用いた gray-scale SHI より画像描出性 に優れるともされており ${ }^{5)}$, 今後の追試も必要であろ う.またこのような基本画像の増強効果を定量的に TIC で解析し, 得られたパラメータを画像化する parameter imaging も導入されているが(Table 1), やは り基本画像の改善が重要と思われる.

一方, 本シリーズで導入した UHI は, 組織からの harmonic 信号が混在する整数倍の harmonic 成分を 避けて, 2 倍と 3 倍間の高調波成分を画像化するもの である. 従って, 当然組織からの信号が減弱され背景 


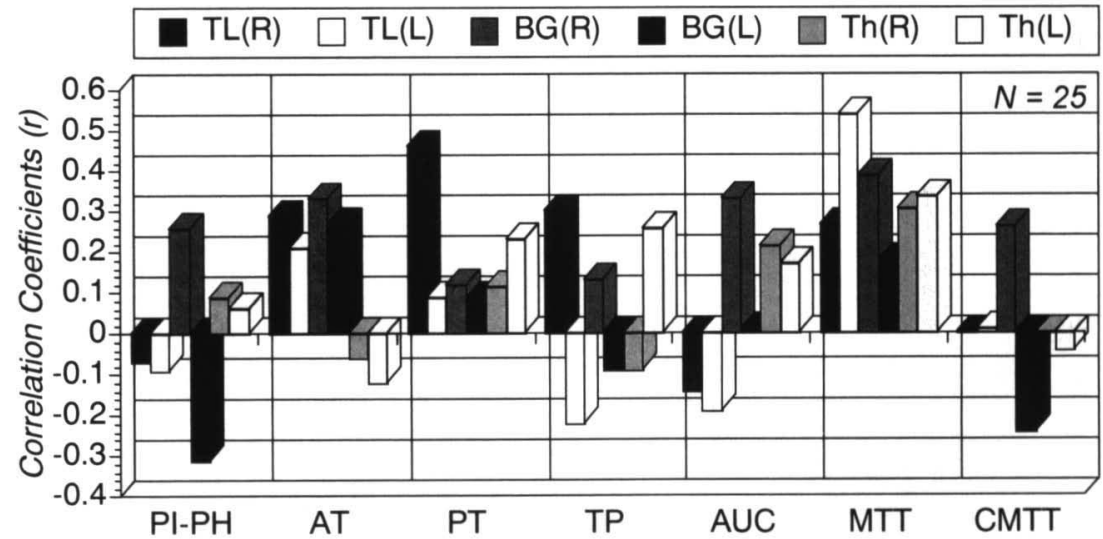

Fig. 2 (C) : HPI と DCT 各パラメータの相関係数 ${ }^{8)}$

各 ROIにおける両パラメータ間の相関係数を図示. MTT が他と比較して高い相関を 示した.

250

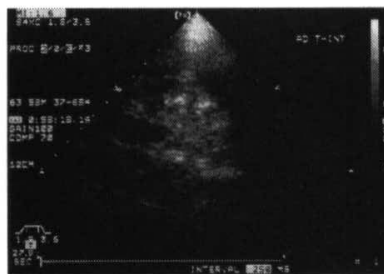

1500

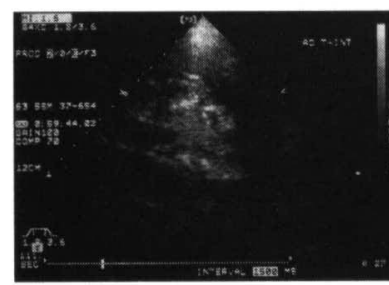

2000

3000

4000

1000

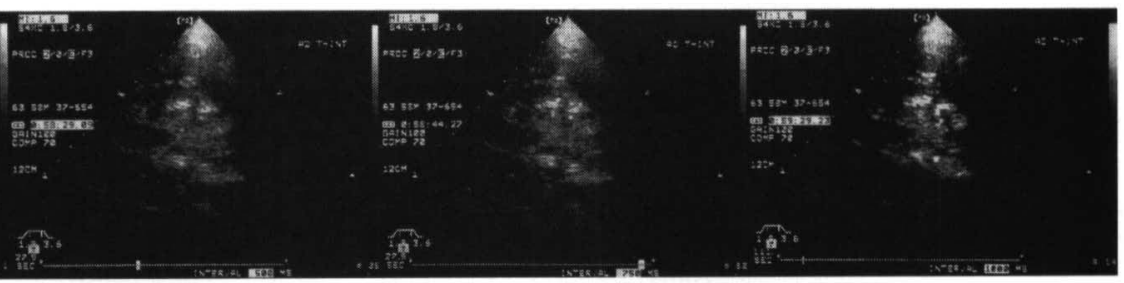

(3)

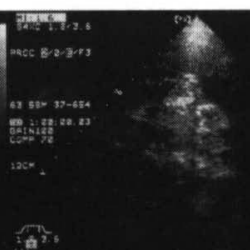

ants
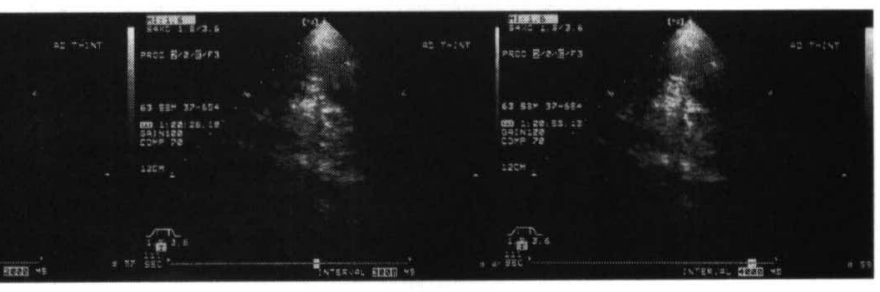

Fig. 3 持続静注法による定量解析

Fig. 3 (A) : 58 男, 右中大脳動脈領域の脳塞栓例にて, パルス間隔を $250 \mathrm{~ms} \sim 4,000$ $\mathrm{ms}$ まで変化させ, 右側頭空からの画像を描出した (左が前頭側).
画像の描出性は低下するが, 増強効果との SN 比は改 善される. しかし, 本シリーズの SHI との比較では, 画像描出性が優れているとは言えなかった。これに関 する最大の要因は, 頭蓋骨による超音波の減衰と考え られ，UHI では SHI より高調波成分を使用するため, 受信周波数上昇に伴う音圧の隇衰を受け易くなったた めと推測される.この送信・受信周波数の上昇に伴う 頭蓋骨による超音波音圧の減衰によると推測される画
像描出性の不良は, 本シリーズの PHI でも認められ た. 従って, 頭蓋骨透過性の改善という意味からは, $1 / 2$ 倍の harmonic 成分を使用し低い受信周波数とな る subharmonic imaging が適切かも知れない.さらに 頭蓋骨切除例でも, SHI に比べUHI の増強効果は必ず しも優れていなかった (Fig. 1B) ことに加え, 背景画 像の描出性低下は脳の局在判定に必要な増強部位同定 の確実性を妨げるものであり,この意味からも UHI 


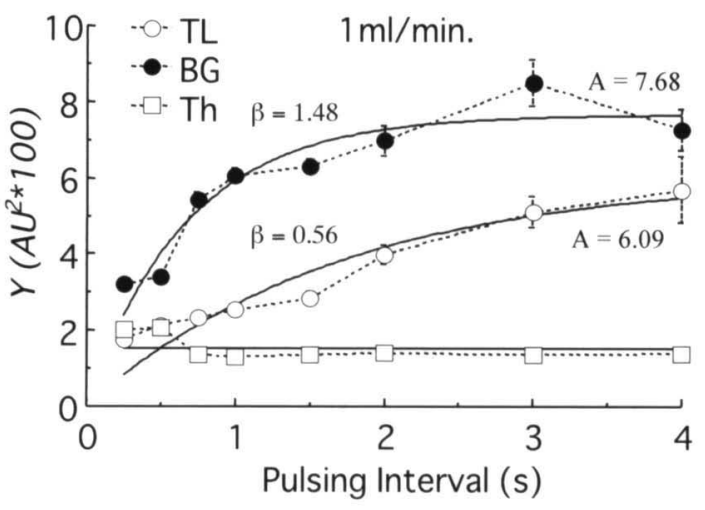

Fig. 3 (B) : TL，BG，Thの ROIにおけるパルス間隔 と増強強度 (Y) との関係

TL, BG ではパルス間隔の増加に伴いY $\mathrm{Y}$ も昇し, plateau（A）となった.

Resting

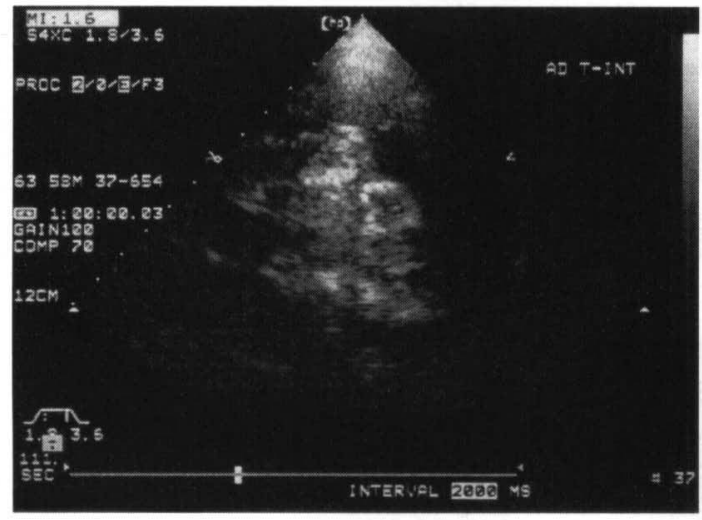

Fig. 3 (C)：ACZ 負荷による脳血管反応性 右側頭空より ACZ 負荷前 (Resting) ・後 (Acetazolamide) で比較, 負荷後に増強強 度は上昇し，範囲も拡大している。

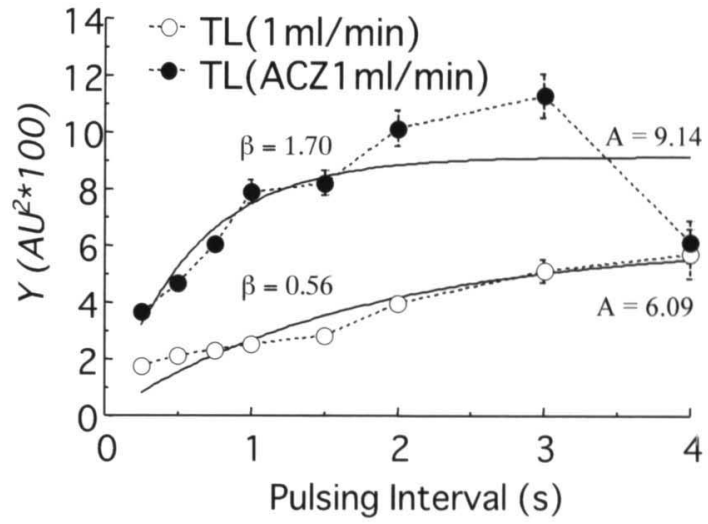

Fig. 3 (D)：脳血管反応性の定量解析

$\mathrm{ACZ}$ 負荷後には, 増強強度の上昇が著明で, curve fitting の傾きも急峻となり, 血流速 $(\beta)$ と血流量 $(\mathrm{A})$ の 両者の上昇が認められた。

Acetazolamide

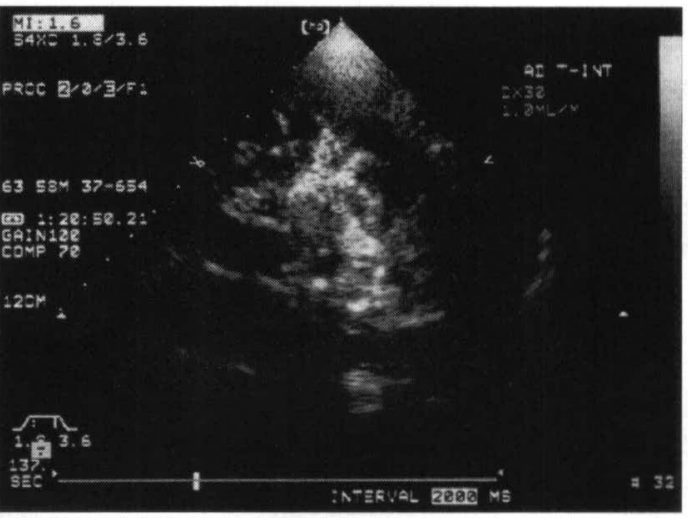

は脳組織灌流画像の描出には不適と考えられた。

b) HPIによる脳組織灌流の定量性

HPI による脳組織灌流の定量性は, 従来 IBS による SHI 用いてDCTや perfusion MRI ととと同様の bolus 静注法により解析されている (Table 1).この古 典的な dye-dilution principleに基つくく time-activity curve の各種パラメータによる解析は, 脳組織への流 入動脈と脳組織自体における ACU の評価から脳血液 量 $(\mathrm{CBV})$ を求めることが出来, さらに MTT との関 係から局所脳血流量（rCBF）を推測できる ${ }^{6)}$. 実験的
に骨弁を除去した犬のPDIを用いた検討では, radiolabeled-microsphere 法による $\mathrm{rCBF} と \mathrm{AUC} と$ の相関が指摘されている7). 一方, 臨床的な SHIによ る経頭蓋的評価に関して, 神経放射線学的な脳循環測 定法との関係をみた報告は, 我々の DCT との相関 ${ }^{8)}$ と perfusion MRI との関係を検討した報告がある ${ }^{9}$. 我々の検討では HPI の各種パラメータのうち, peak intensity と ACUは，深度依存的に低下し(Fig. 2B)， 相関低下の主因であった ${ }^{81}$ 。このような頭蓋骨や深度 依存性の超音波減衰による影響は, 早期より指摘され 
ている”. 我々のシリーズでは,これらのパラメータの 中でも MTTに比較的相関係数が高い傾向が得られた (Fig. 2C) $)^{8}$ が, 犬の実験ではMTTと流量との関係が 低かったとされ，その原因として高流量での bubble saturation が指摘されている ${ }^{10)}$. IBS 法による SHI で は dynamic range が狭く，その意味から B-modeによ るSHIの方が適切かも知れない.しかし, PHIを用い た in-vitroの奏験では, peak intensity, AUC, time to maximal enhancement と流量との高い相関も指摘さ れており ${ }^{\prime \prime \prime}$, 臨床例でも peak intensity time to peak intensityで除した positive gradientが良いとさ

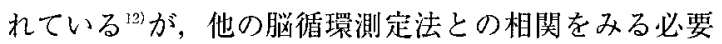
があろう。さらにPerfusion MRI との関係でも, 直線的 な相関はみられなかっだ

またこのような頭蓋骨や深度依存性の超音波の減衰 による影響を除外するため，測定部位を同一にして評 価するという意味から，我々は $\mathrm{ACZ}$ 反応性測定を臨 床応用している。これでは，本シリーズのように $\mathrm{TCD}^{13)} \mathrm{DCT}$ によ反応性との関係が得られた、今 後の更なる症例の蓄積が必要であるが, 定量性評侕の 一つの解決法になると考充病態解析に応用してい $\Xi^{14 !}$.

この bolus 静注法の限界を解決する手段として, 造 影剂の持続静注法による心筋灌流の定量法が導入"2 れ，脳組織灌流の評価にも応用されている(Table 1). これは送信パルス幅 $(\mathrm{t})$ と組織の增強強度 $(\mathrm{Y})$ との 間には $Y=A\left(1-\mathrm{e}^{-\beta t}\right)$ と言う関係があり，Aが plateau となる増強強度で微小血管内の断面積すなわち CBV を表し， $\beta$ は増強強度の上昇率で流速を表すとされて いる2．脸への応用として犬の頭湆骨切除による実験 では, $\mathrm{Ax} \beta$ と radiolabeled-microsphere 法による $\mathrm{CBF}$ との相関が指摘されている. しかし, 経頭蓋的な正常 例での检討では interindividual variation が問題と なっている，我々の経験でもその傾向は得ているが, 深度依存性の強度の減衰の影響を受けるのは同様であ り (Fig. 3B)， ACZ 反応性への応用も今後の課題であ ろう (Figs. 3C, 3D).

さらに最近では, bolus 法や持続静注法を用いて, 脳 組織の堌強效果が最大となった時点からの微小気泡の 破壞を伴う減衰曲線の解析 (diminution 法や depletion 法) も試みられている (Table 1).

何れにしても, 経頭蓋 HPI は, 超音波造影剤と診断 機器の特性とも関連した頭蓋骨などの組織透過性に大 きく依存し,今後の更なる改善や検討が必須であるが,
脳卒中急性期のベッドサイドで比較的容易に反復可能 ‘な脳循環測定法としての意義が見达まれる。

\section{文献}

1) Postert T, Muhs A, Meves $\mathrm{S}$, et al : Transient response harmonic imaging: an ultrasound technique related to brain perfusion. Stroke 29 : $1901-1907,1998$

2) Wei K, Jayaweera AR, Firoozan S, et al : Quantification of myocardial blood flow with ultrasoundinduced destruction of microbubbles administered as a constant venous infusion. Circulation $97: 473-483,1998$

3) Seidel G, Algermisen C, Christoph A, et al : Visualization of brain perfusion with harmonic gray scale and power Doppler technology : an animal pilot study. Stroke $31: 1728-1734,2000$

4) Pohl C, Tiemann $K$, Schlosser $T$, et al : Stimulated acoustic emission detected by transcranial color Doppler ultrasound : a contrast-specific phenomenon useful for the detection of cerebral tissue perfusion. Stroke 31 : 1661-1666, 2000

5) Postert T, Hoppe P. Federlein J, et al : Contrast agent specific imaging modes for the ultrasonic assessment of parenchymal cerebral echo contrast enhancement. J Cereb Blood Flow Metab $20: 1709-1716,2000$

6) Meier P, Zierler LK : On the theory of the indicator-dilution method for measurement of blood flow and volume. J Appl Physiol 6:731744,1954

7) Greenberg RS, Taylor GA, Stapleton JC, et al: Analysis of regional cerebral blood flow in dogs, with an experimental microbubble-based us contrast agent. Radiology $201: 119-123,1996$

8）塩具敏之, 常塚二春, 今井啓輔ら：超音波造影剤に よる経頭盖 harmonic perfusion imaging $\sigma$ 脳循環 测定法としての臨床的意義. 神経外傷 $24: 77-$ 82,2001

9) Meves SH, Wilkening W. Thies T, et al : Comparison between echo contrast agent-specific imaging modes and perfusion-weighted magnetic resonance imaging for the assessment of brain perfusion. Stroke 33:2433-2437, 2002

10) Claassen L, Seidel G, Algermissen C : Quantification of flow rates using harmonic grey-scale imaging and an ultrasound contrast agent : an in vitro and in vivo study. Ultrasound Med Biol $27: 83-$ 88.2001

11) Ugolini $P$. Delouche $A$, Herment $A$, et al : In vitro flow quantification with contrast power Doppler 
imaging. Ultrasound Med Biol 26: 113-120, 2000

12) Harrer JU. Klotzsch $C$ : Second harmonic imaging of the human brain : the practicability of coronal insonation planes and alternative perfusion parameters. Stroke 33:1530-1535, 2002

13）壏貝敏之, 常塚千春, 越村満理子ら：経頭蓋 Harmonic Perfusion Imaging と経頭盖超音波 Doppler 法による脳血管反応性の評洒. 脳循環代謝
$14: 55-56,2002$

14) Shiogai $T$, Uebo $C$, Makino $M$, et al : Acetazolamide vasoreactivity in vascular dementia and persistent vegetative state evaluated by transcranial harmonic perfusion imaging and Doppler sonography. Ann NY Acad Sci $977: 445-453$, 2002

\author{
Abstract \\ Ultrasonic evaluation of brain tissue perfusion by transcranial contrast \\ enhanced harmonic imaging

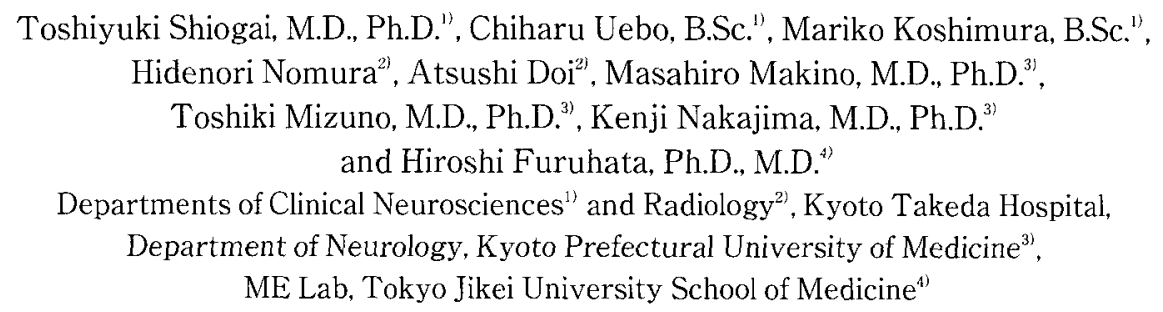

To clarify the clinical significance of transcranial harmonic perfusion imaging (HPI), we investigated qualitative comparisons between second- and ultra-harmonic imaging (SHI, UHI), power Doppler harmonic imaging (PHI), and quantitative correlations with dynamic CT (DCT) and/or transcranial Doppler (TCD) during acetazolamide vasoreactivity tests in neurological patients. Methods : The contrast images after a bolus Levovist ${ }^{\boxplus}$ injection were compared on the basis of the transmitting and receiving frequencies ( $\mathrm{MHz}$ ) of SONOS 5500, SHI and PHI (1.8/3.6) utilizing an S4 transducer $(n=28)$, and UHI $(1.3 / 3.6)$. SHI $(1.3 / 2.6)$, and PHI (1.3/2.6 and 1.6/3.2) utilizing an S3 transducer $(n=10)$. HPI parameters from time-intensity curves in the temporal lobe, basal ganglia, and thalamus were correlated with those of DCT parameters $(n=25)$, and with TCD and DCT parameters during vasoreactivity tests $(n=12)$. Refill kinetics during continuous Levovist ${ }^{\circledR}$ infusion was analyzed at rest and during vasoreactivity tests. Results : a) Visualization of contrast effects was more sensitive in SHI, with a particularly low receiving frequency of $2.6 \mathrm{MHz}$, than UHI or PHI. b) Correlation of parameters was reduced in inter-individual variations, however mean transit time indicated closer correlations. Vasoreactivity of HPI tended to correlate with that of DCT and/or TCD. Conclusions : HPI allows qualitative and relatively quantitative comparisons of brain tissue perfusion, is non-invasively repeatable at bedside, and has a clinical significance in the evaluation of treatment and follow-ups for ischemic stroke patients.

(Jpn J Stroke 24:526-534, 2002)

Key words : transcranial harmonic brain tissue perfusion imaging, echo-contrast agents, dynamic CT, transcranial Doppler, acetazolamide cerebral vasoreactivity 